International Journal of Mechanical Engineering and Technology (IJMET)

Volume 12, Issue 3, March 2021, pp. 20-36. Article ID: IJMET_12_03_003

Available online at https://iaeme.com/Home/issue/IJMET?Volume=12\&Issue=3

ISSN Print: 0976-6340 and ISSN Online: 0976-6359

DOI: https://doi.org/10.34218/IJMET.12.3.2021.003

C IAEME Publication

Scopus Indexed

\title{
MODELING AND OPTIMIZATION OF A DESALINATION UNIT USING HUMIDIFICATION-DEHUMIDIFICATION HDH PRINCIPLE
}

\author{
Mohamed Osama, Ehab M. Mina and Raouf N. Abdelmessih \\ Faculty of Engineering, Mechanical Power Department, Ain Shams University, Egypt
}

\begin{abstract}
Humidification-Dehumidification desalination (HDH) process is an existing, widely-spread and developing technology. This technology has high potential to serve people who suffer lack of water in undeveloped, poor countries as it could be built and operated using locally available natural resources.
\end{abstract}

HDH cycle is considered man-made rain cycle. It utilizes vaporization of water from saline solution into a carrier gas (usually air). Then this saturated air with water vapor passes over a cold surface, leading to condensation process obtaining fresh potable water suitable for human usage.

This paper focuses on the heat and mass transfer processes inside each of the humidifier and the dehumidifier sections. In the humidifier section, counter flow between air and water at atmospheric pressure, where direct contact between air and water occurs. In the dehumidifier section, air flows over a coil containing flowing water in opposite direction. Based on mass balance and rate equations, the mathematical modeling equations of both humidifier and dehumidifier sections are established. Output results of simulation process depend on liquid-gas ratio, entering temperature of air in addition to water temperature entering both sections as well as the geometry of both humidifier and dehumidifier.

These design parameters can provide great reference significance for the design, optimization and regulation of humidifiers and dehumidifiers sections.

Keywords: Humidifier, Dehumidifier, Humidification Dehumidification Desalination, Modeling, heat and mass transfer, Vaporization, Thermodynamic balance, Simulation, Heat exchanger, cross flow.

Cite this Article: Mohamed Osama, Ehab M. Mina and Raouf N. Abdelmessih, Modeling and optimization of a desalination unit using humidification-dehumidification HDH principle, International Journal of Mechanical Engineering and Technology (IJMET), 12(3), 2021, pp.20-36.

https://iaeme.com/Home/issue/IJMET?Volume=12\&Issue=3 


\section{NOMENCLATURE}

\begin{tabular}{|c|c|c|c|}
\hline A & cross section area $\left[\mathrm{m}^{2}\right]$ & $\mathrm{V}$ & velocity $\left[\mathrm{m} \mathrm{s}^{-1}\right]$ \\
\hline $\mathrm{A}, \mathrm{B}, \mathrm{C}$ & antoine equation constants & Sc & Schmidt Number \\
\hline $\mathrm{a}$ & $\begin{array}{l}\text { surface area to volume ratio }\left[\mathrm{m}^{-}\right. \\
\left.{ }^{1}\right]\end{array}$ & & \\
\hline$c_{p}$ & specific heat $\left[\mathrm{J} \mathrm{kg}^{-1} \mathrm{~K}^{-1}\right]$ & \multicolumn{2}{|c|}{ Greek letters } \\
\hline d & section diameter $[\mathrm{m}]$ & $\phi$ & relative humidity \\
\hline$d x$ & section step $[\mathrm{m}]$ & $\mu$ & dynamic viscosity $\left[\mathrm{kg} \mathrm{m}^{-1} \mathrm{~s}^{-1}\right]$ \\
\hline $\mathrm{h}$ & $\begin{array}{l}\text { heat transfer coefficient }\left[\mathrm{W} \mathrm{m}^{-2}\right. \\
\mathrm{K}]\end{array}$ & $\rho$ & density $\left[\mathrm{kg} \mathrm{m}^{-3}\right]$ \\
\hline $\mathrm{h}_{\mathrm{fg}}$ & $\begin{array}{l}\text { latent heat of vaporization }\left[\mathrm{J} \mathrm{kg}^{-}\right. \\
\left.{ }^{1}\right]\end{array}$ & $\omega$ & humidity ratio \\
\hline $\mathrm{h}_{\mathrm{m}}$ & mass transfer coefficient $\left[\mathrm{m}^{-1}\right]$ & \multirow{2}{*}{\multicolumn{2}{|c|}{ Subscripts }} \\
\hline $\mathrm{k}$ & $\begin{array}{l}\text { thermal conductivity }\left[\mathrm{W} \mathrm{m}^{-1} \mathrm{~K}^{-}\right. \\
\left.{ }_{1}\right]\end{array}$ & & \\
\hline $\mathrm{L}$ & section length $[\mathrm{m}]$ & atm & atmosphere \\
\hline $\mathrm{L}_{\mathrm{c}}$ & section characteristic length $[\mathrm{m}]$ & $\mathrm{a}$ & air \\
\hline Le & Lewis number & $\mathrm{c}$ & coil \\
\hline$\dot{m}$ & mass flow rate $\left[\mathrm{kg} \mathrm{s}^{-1}\right]$ & $\mathrm{d}$ & dry \\
\hline MR & water to air mass flow rate ratio & $\mathrm{f}$ & film \\
\hline $\mathrm{Nu}$ & Nusselt Number & $\mathrm{i}$ & interface \\
\hline $\mathrm{p}$ & pressure [bar] & $\mathrm{p}$ & packing \\
\hline $\operatorname{Pr}$ & Prandtl Number & sat & saturation \\
\hline $\mathrm{R}$ & $\begin{array}{l}\text { universal gas constant }\left[\mathrm{J} \mathrm{kg}^{-1} \mathrm{~K}^{-}\right. \\
\left.{ }_{1}\right]\end{array}$ & $\mathrm{w}$ & water \\
\hline $\operatorname{Re}$ & Reynolds Number & wt & wet \\
\hline $\mathrm{T}$ & temperature $\left[{ }^{\circ} \mathrm{C}\right]$ & & \\
\hline
\end{tabular}

\section{INTRODUCTION}

Modern life style depends on water in several aspects of life. Not only for drinking, but also for irrigation, manufacturing, cleaning, and power production (desal water is vital in cooling heat rejection devices for instance) [1]. Water available around could be divided into several categories. Unfortunately, potable water, which is suitable for human consumption is scarce and require considerable amount of energy to reach that level of low salinity. [2, 3].

Salt water, on the other hand, is widely available. It could be further categorized into three main categories: Brackish water, Intermediate water and Salt water [2,3].

I- Brackish water: salinity ranges between 1,000 to $15,000 \mathrm{ppm}$. It is salt water and fresh water mixed together. It is saltier than fresh water but not as salty as the sea water [3].

II- Intermediate water: salinity ranges between 15,000 to $35,000 \mathrm{ppm}$. It is relatively saltier than brackish water but still less than sea water. As salinity increases, extraction of fresh water out of a saline solution becomes harder. So extraction of fresh water out of intermediate water requires more developed techniques than brackish water which is easier [3].

III- Salt water: salinity ranges between 35,000 to $45,000 \mathrm{ppm}$. It is the water type with most salinity percentage. Most sea water around the world is within this salinity range. Sea water is considered the hardest type of water to extract out of it fresh water due to its high salt concentration [3].

Ppm indicates part per million which is equivalent to one milligram of salt per one liter of water $(\mathrm{mg} / \mathrm{L})$. For proper selection of one of the below listed desalination techniques, water 
shall be properly analyzed, knowing water contaminants and suspended solid to be removed. Some of these techniques are simple, of relatively low costs and others involve high initial and running costs in addition to the complexity of the cycle.

Desalination techniques are divided into 2 major divisions [3] according to the technology used. The First technology is thermal technology, which involves heating of saline solution and collecting the condensed vapor for fresh water production. Second one is membrane technology, which uses a semi permeable membrane element in desalination process [2, 3, 4]. Several methods are included below each of these technologies. Famous examples of these methods are shown in the following table and readers are invited to read further on other technologies in the shown references.

Table 1 different desalination technologies [3-11]

\begin{tabular}{|l|l|}
\hline Thermal technology & Membrane technology \\
\hline Multi-stage flash distillation (MSF) & Electro dialysis (ED) \\
\hline Multi effect distillation (MED) & Electro dialysis reversal (EDR) \\
\hline $\begin{array}{l}\text { Humidification dehumidification } \\
\text { desalination (HDH) }\end{array}$ & Reverse Osmosis (RO) \\
\hline
\end{tabular}

HDH comes under the umbrella of thermal technology. The cycle has a unique advantage of being suitable to small scale applications corresponding to small (new communities) as it is feasible to build and operate with small budget compared to MSF and MED [11,12].

Despite of its low GOR, it has high potential to improve its efficiency. Therefore, extensive researches are needed to enhance the cycle performance.

This study focuses on the optimum design of the humidifier and the dehumidifier.

\section{MODELING HUMIDIFICATION - DEHUMIDIFICATION DESALINATION}

Figure (1) shows the simplest construction for HDH plant which contains three main subsystems which are humidifier sub-cycle, solar heater sub-cycle and dehumidifier Sub-cycle $[7,8,12,13]$.

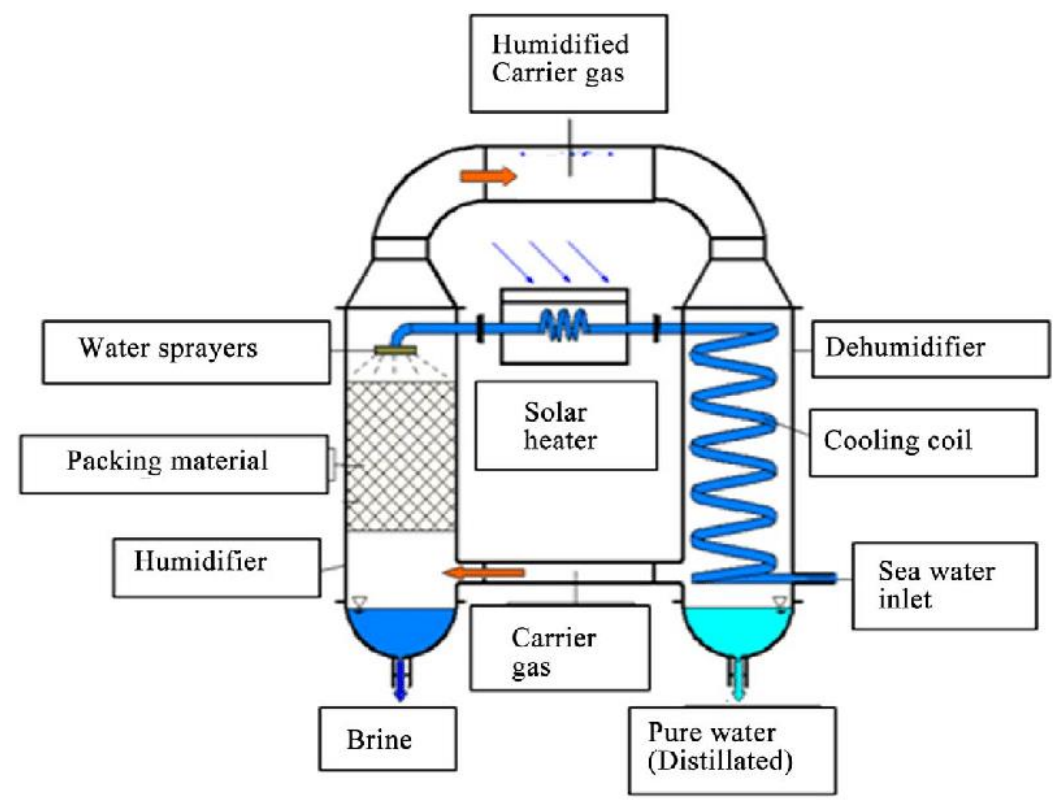

Figure $1 \mathrm{HDH}$ cycle 


\subsection{Modeling Humidifier}

The first sub-cycle is the humidifier section, in which hot water is sprayed over relatively cold, low water vapor air. This process results in increasing both temperature and relative humidity of the air going to the dehumidifier for condensation process.

Sprayed water salinity increases as a percentage of it is vaporized to the air. This output is a brine solution, with increased salinity than the inlet feed, which is either recycled, after being mixed with the inlet feed to make up for the water evaporated, or discharged back to salt water source $[8,12,13,14,15]$.

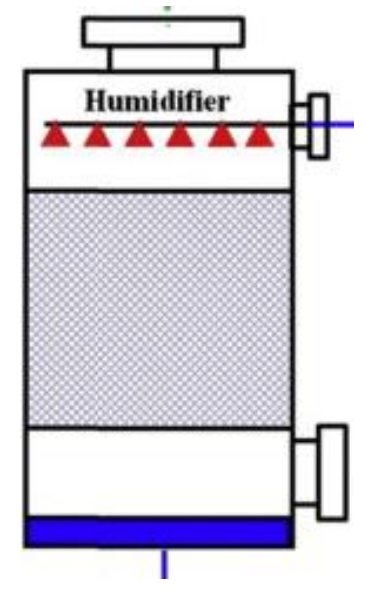

Figure 2 Humidifier schematic section.

\subsubsection{Humidifier governing equations:}

Assumptions are made up by moving upwards with air direction across the sprayed hot water which is in direct contact with air. Assumption of water temperatures at humidifier inlet and exit are corrected through several iterations. As air comes into contact with hot water, its temperature and relative humidity increases, leaving the humidifier sub-cycle, entering dehumidifier sub-cycle and condensation process begins.

$$
\frac{\mathrm{dT}_{\mathrm{a}}}{d y}=\left(\frac{1}{\dot{m}_{\mathrm{a}} * \mathrm{c}_{\mathrm{pa}}}\right) *\left[\mathrm{~h}_{\mathrm{a}} * \mathrm{~A} * \mathrm{a}_{\mathrm{p}} *\left(\mathrm{~T}_{\mathrm{i}}-\mathrm{T}_{\mathrm{a}}\right)\right]
$$

Equation (1) describes the air temperature change which is expected to increase on moving upwards [16].

$$
\mathrm{T}_{\mathrm{i}}=\frac{\left(\mathrm{h}_{\mathrm{w}} * \mathrm{~T}_{\mathrm{w}}\right)+\left(\mathrm{h}_{\mathrm{a}} * \mathrm{~T}_{\mathrm{a}}\right)+\left[\mathrm{h}_{\mathrm{m}} * \mathrm{~h}_{\mathrm{fg}} *\left(\omega_{\mathrm{a}}-\omega_{\mathrm{i}}\right)\right]}{h_{a}+h_{w}}
$$

Equation (2) gives the interface temperature between air and water in a direct contact heat and mass transfer process [16].

$$
\begin{aligned}
\mathrm{h}_{\mathrm{a}} & =\frac{N u * k}{L_{c}} \\
\mathrm{Nu} & =0.023 * \operatorname{Pr} *\left(\mathrm{Re}^{0.8}\right) \\
\mathrm{Re} & =\frac{\rho_{a} * \mathrm{v}_{\mathrm{a}} * L_{c}}{\mu} \\
\mathrm{V}_{\mathrm{a}} & =\frac{\dot{m}_{a}}{\rho_{a} * \mathrm{~A}} \\
\rho_{\mathrm{a}} & =\frac{P_{a t m}}{R *\left(273+T_{a}\right)}
\end{aligned}
$$

Equation (4), (5), (6) and (7) are established for the calculation of equation (3) which is air heat transfer coefficient [16]. 
Mohamed Osama, Ehab M. Mina and Raouf N. Abdelmessih, Modeling and optimization of a desalination unit using humidification-dehumidification $\mathrm{HDH}$ principle

$$
\begin{aligned}
& \mathrm{P}_{\text {sat a }}=10^{\wedge}\left[\left(\mathrm{A}-\frac{\mathrm{B}}{\mathrm{C}+T_{a}}\right) * 0.001315\right] \\
& \mathrm{P}_{\mathrm{a}}=\phi * \mathrm{P}_{\text {sat a }} \\
& \omega_{\mathrm{a}}=0.622 *\left[\frac{P_{a}}{P_{\text {atm }}-P_{a}}\right]
\end{aligned}
$$

Equation (10) gives air humidity ratio at humidifier section inlet. Accordingly, $\omega_{\mathrm{i}}$ can be deduced by using same equations at water temperature [16].

$$
\Omega_{\mathrm{I}}=0.622 *\left[\frac{P_{i}}{P_{a t m}-P_{i}}\right]
$$

$\mathrm{P}_{\mathrm{i}}$ is calculated at assumed water as:

$$
\mathrm{P}_{\mathrm{i}}=10^{\wedge}\left[\left(\mathrm{A}-\frac{\mathrm{B}}{\mathrm{C}+T_{w}}\right) * 0.001315\right]
$$

Equation (12) gives us the pressure at interface layer between air and water. All of the previous calculations, deductions and equations are established for the calculation of the second temperature change which is falling water temperature change in equation (13) [16].

$$
\frac{d T_{w}}{d y}=\frac{\mathrm{h}_{\mathrm{w}} * \mathrm{~A} * a_{p}}{\dot{m}_{w} * C_{w}} *\left(\mathrm{~T}_{\mathrm{i}}-\mathrm{T}_{\mathrm{w}}\right)
$$

Equation (14) gives us the change in air humidity ratio which is expected to increase on moving upwards [16].

$$
\frac{d \omega_{a}}{d y}=\frac{h_{m} * \rho_{a} * \mathrm{~A} * a_{p}}{\dot{m}_{a}} *\left(\omega_{\mathrm{i}}-\omega_{\mathrm{a}}\right)
$$

For next steps, Euler integration method is used to deduce change in each step.

$$
\begin{aligned}
& \mathrm{T}_{\mathrm{a}}(\mathrm{i}+1)=\mathrm{T}_{\mathrm{a}}(\mathrm{i})+\int_{x i}^{x i+1}\left(\frac{\mathrm{dT}_{\mathrm{a}}}{d y}\right) d x \\
& \mathrm{~T}_{\mathrm{w}}(\mathrm{i}+1)=\mathrm{T}_{\mathrm{w}}(\mathrm{i})+\int_{x i}^{x i+1}\left(\frac{\mathrm{dT}_{\mathrm{w}}}{d y}\right) d x \\
& \omega_{\mathrm{a}}(\mathrm{i}+1)=\omega_{\mathrm{a}}(\mathrm{i})+\int_{x i}^{x i+1}\left(\frac{\mathrm{d} \omega_{\mathrm{a}}}{d y}\right) d x
\end{aligned}
$$

Where (i) indicates the step the model is computing at or the step at which the model is standing, (i+1) indicates the upcoming or the next step at which the results of equation (15), (16) and (17) will be the initial conditions for the next step.

\subsubsection{Humidifier performance curves}

Figure (3), (4) and (5) state the air behavior on introducing it to humidifier at $35^{\circ} \mathrm{C}, 40^{\circ} \mathrm{C}$ and $45^{\circ} \mathrm{C}$ respectively. Output air temperature is predictable at any inlet temperature and rising along humidifier sub-cycle.

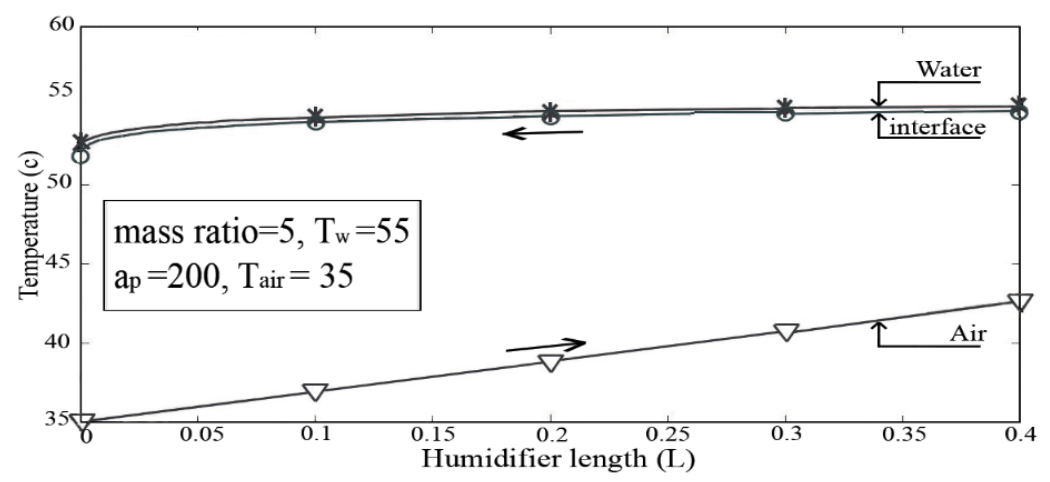

Figure 3 Air temperature behavior at $35^{\circ} \mathrm{C}$ inlet 
Various inlet temperatures are introduced to the humidifier section, other parameters as humidifier geometry $\left(\mathrm{L}=40 \mathrm{~cm}, \mathrm{~A}=0.05 \mathrm{~m}^{2}\right), \mathrm{MR}=5$ and $\mathrm{T}_{\mathrm{W}}=55^{\circ} \mathrm{C}$ are maintained at constant values to study how the effect of inlet air temperature only affects the curve behavior and the outlet temperature.

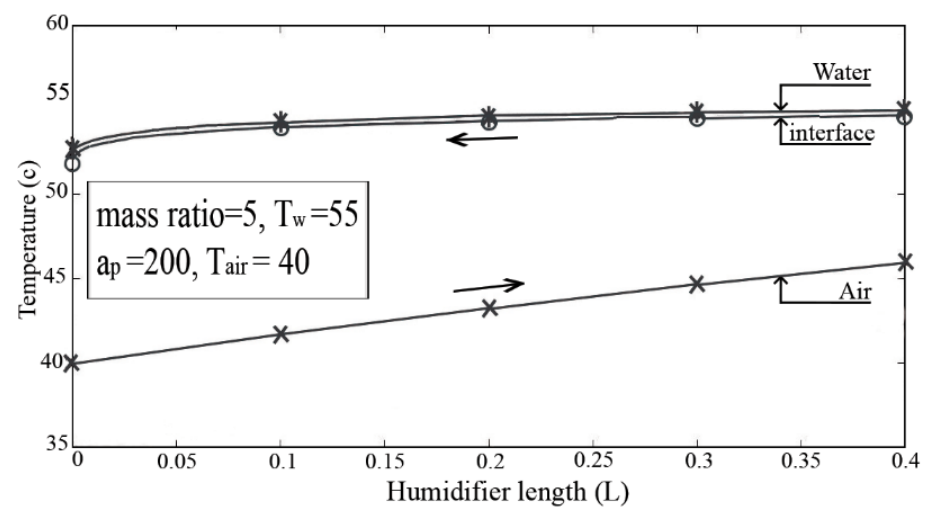

Figure 4 Air temperature behavior at $40^{\circ} \mathrm{C}$ inlet

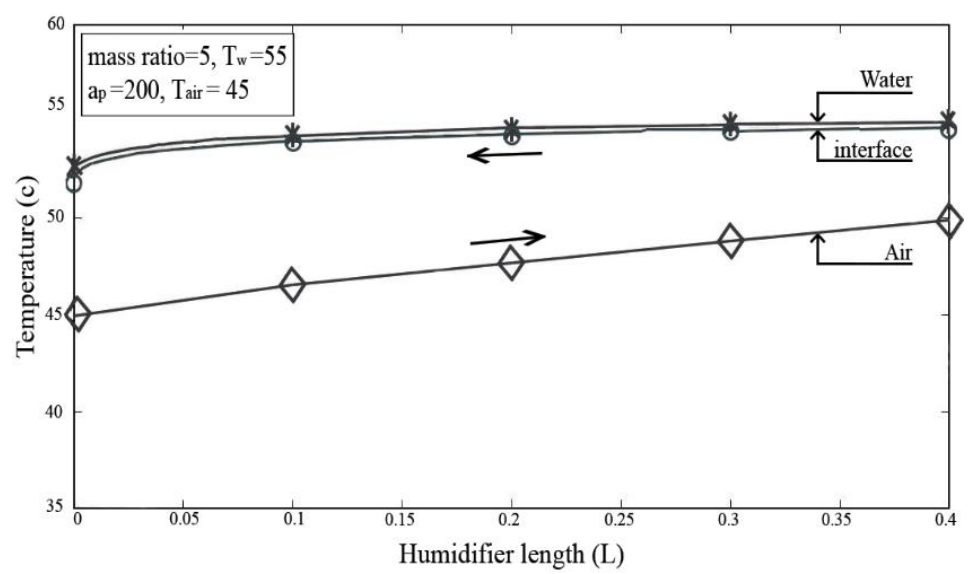

Figure 5 Air temperature behavior at $45^{\circ} \mathrm{C}$ inlet

Figure (6) shows a combined graph for the previous three curves for a clearer representation. Water temperature and interface layer temperature remain constant at inlets $\left(\mathrm{T}_{\mathrm{w}}=55^{\circ} \mathrm{C}\right.$ and $\mathrm{T}_{\mathrm{i}}$ $=54^{\circ} \mathrm{C}$ ), while air temperature curve behavior changes on introducing air at different inlet temperatures to the humidifier $\left(\mathrm{T}_{\mathrm{a}}=35^{\circ} \mathrm{C}, 40^{\circ} \mathrm{C}\right.$ and $45^{\circ} \mathrm{C}$ resp.)

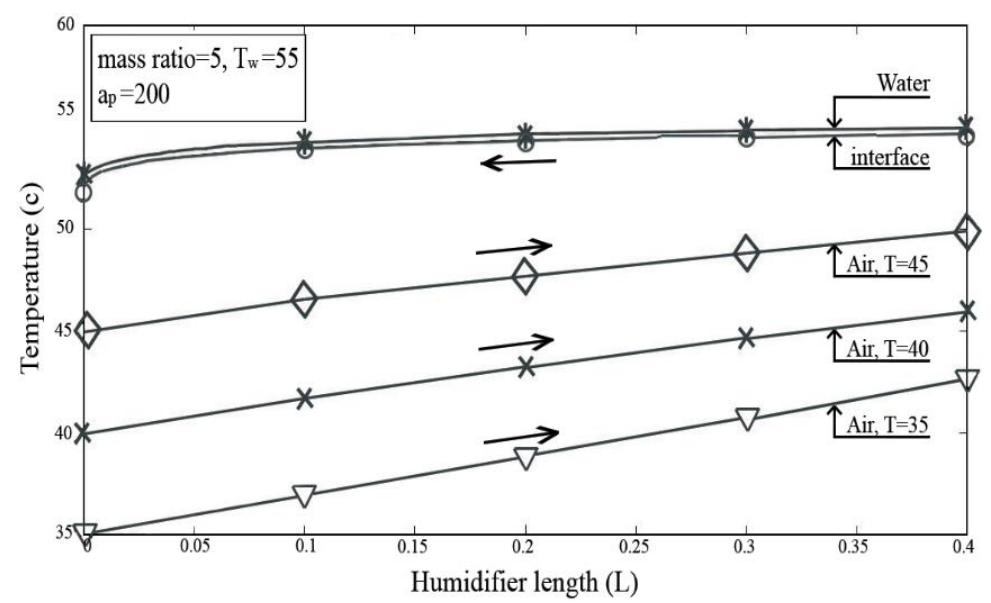

Figure 6 Air, interface and water temperature relations through humidifier at different air inlet temperatures. 
Mohamed Osama, Ehab M. Mina and Raouf N. Abdelmessih, Modeling and optimization of a desalination unit using humidification-dehumidification $\mathrm{HDH}$ principle

Figure (7) and (8) represent air - interface relation along the humidifier sub cycle at different humidifier geometry. Figure (7) represent air - interface relation at a $40 \mathrm{~cm}$ humidifier length while figure (8) represents the same relation at a $60 \mathrm{~cm}$ humidifier length.

The humidifier length affects the air exit temperature. Air inlet temperatures are taken at $\left(35^{\circ} \mathrm{C}, 40^{\circ} \mathrm{C}\right.$ and $45^{\circ} \mathrm{C}$ resp.).

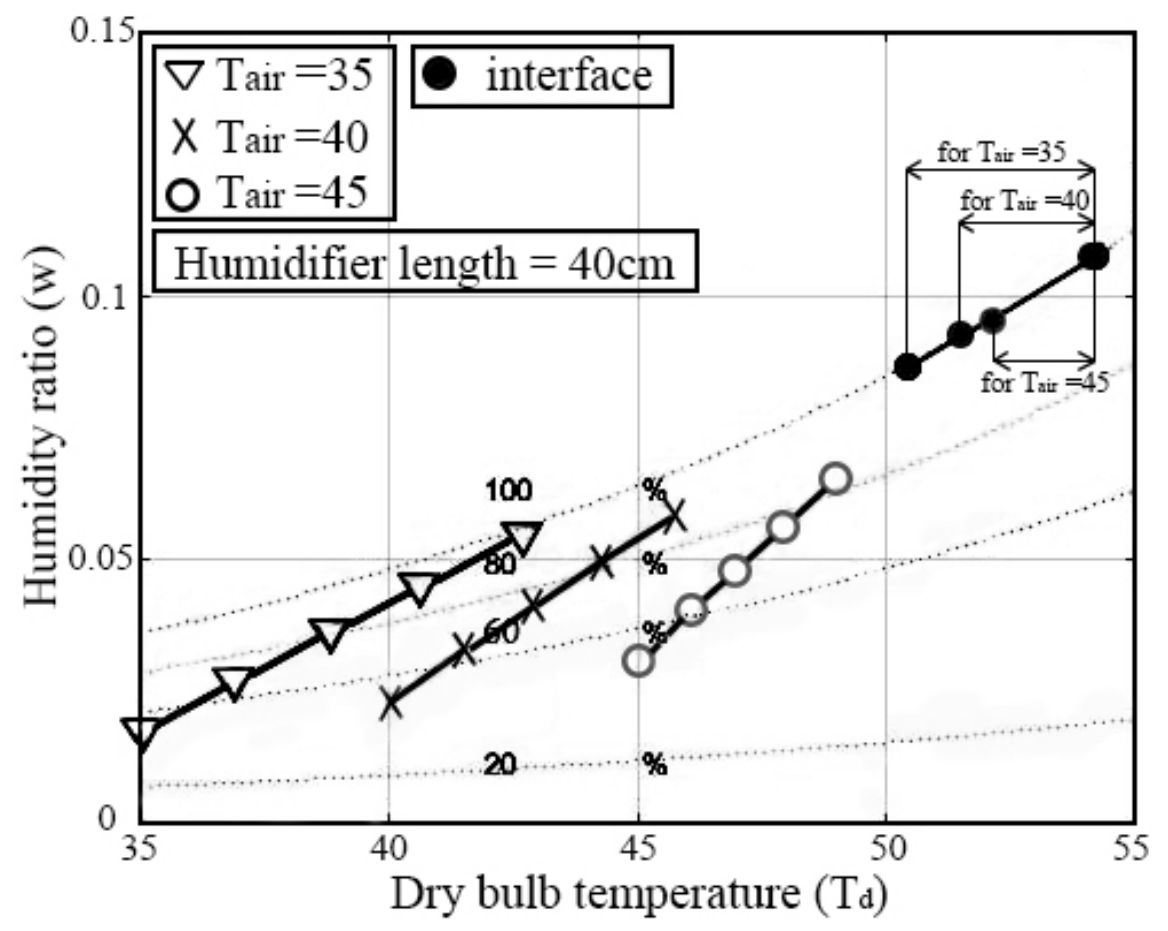

Figure 7 Humidifier cycle representation on

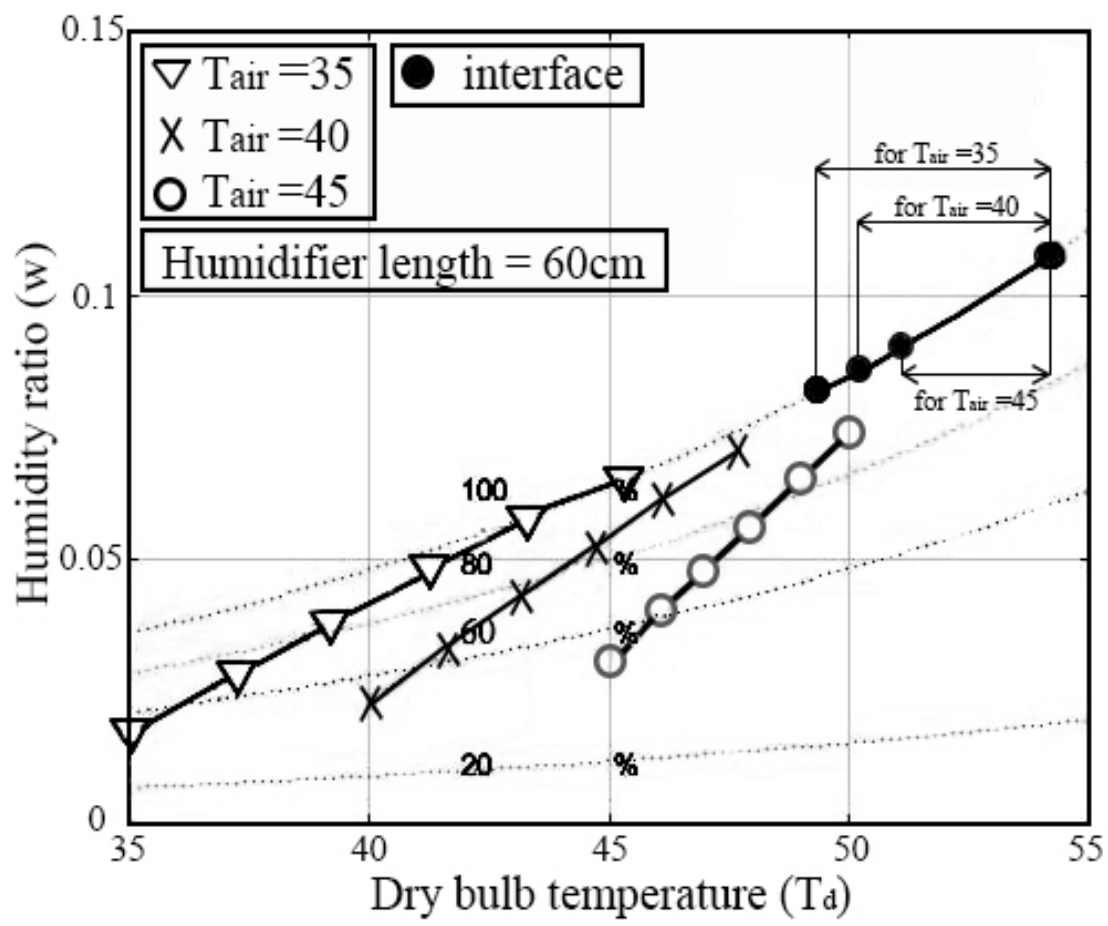

Figure 8 Humidifier cycle representation on psychometric chart at different inlet temperatures psychometric chart at different inlet temperatures of air, $40 \mathrm{~cm}$ length of air, $60 \mathrm{~cm}$ length 
Figure (9) and (10) represents air - interface relations as figure (7) and (8) but with a clearer representation for interface temperatures.

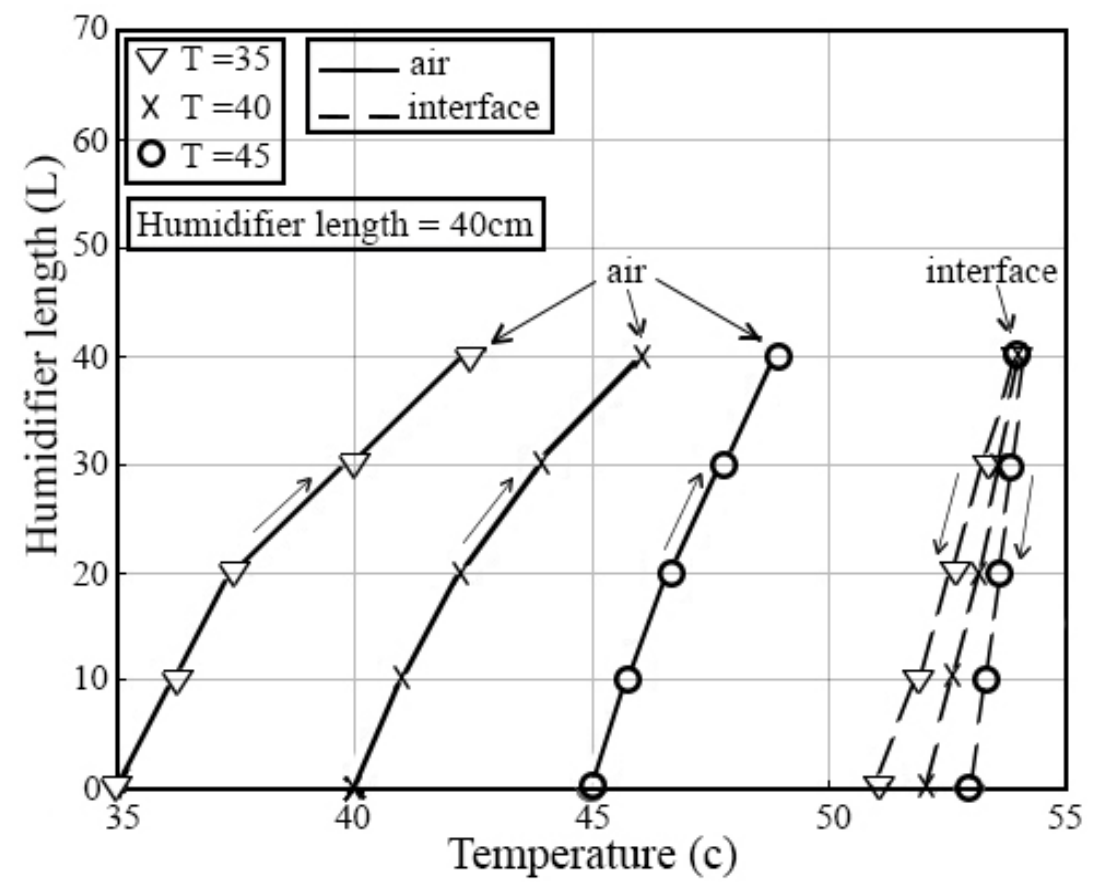

Figure 9 Air-interface relation through

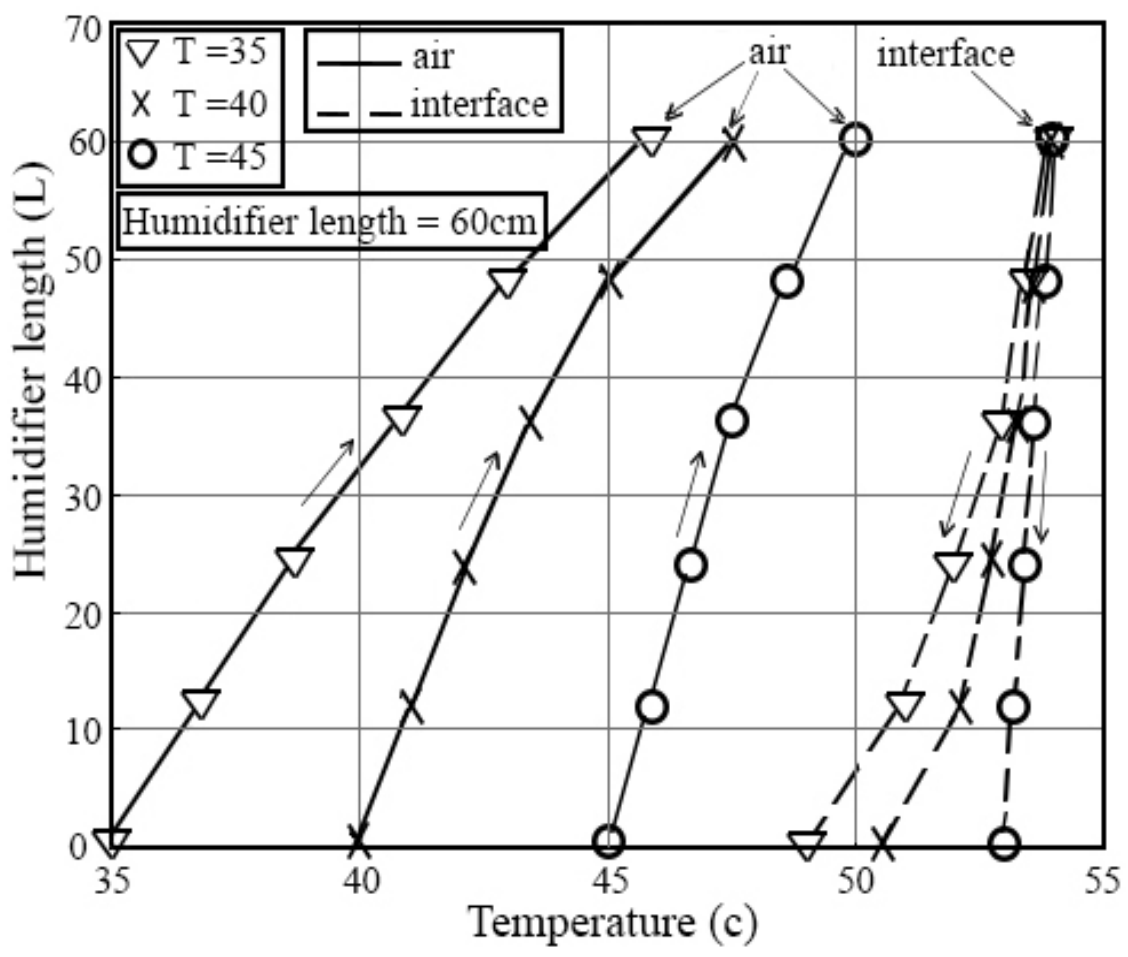

Figure 10 Air-interface relation through

humidifier, $40 \mathrm{~cm}$ length humidifier, $60 \mathrm{~cm}$ length

Figure (11) shows the relation of air inlet temperature with the expected $\Delta \mathrm{T}_{\mathrm{a}}$ across the humidifier for various humidifier lengths $(20 \mathrm{~cm}, 30 \mathrm{~cm}, 40 \mathrm{~cm}, 50 \mathrm{~cm}$ and $60 \mathrm{~cm}$ resp.) and how the expected output temperature increases with the humidifier length. 
Mohamed Osama, Ehab M. Mina and Raouf N. Abdelmessih, Modeling and optimization of a desalination unit using humidification-dehumidification $\mathrm{HDH}$ principle

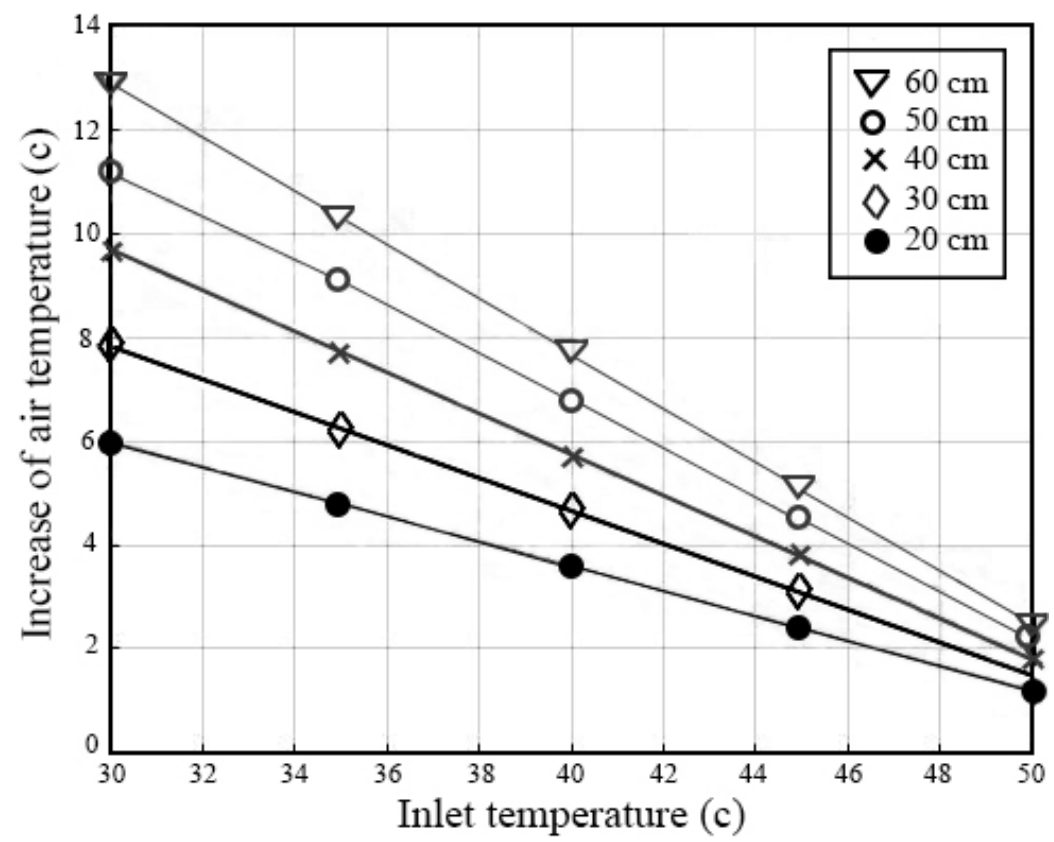

Figure 11 Inlet air temperature and increase in temperature across humidifier for various humidifier lengths.

Figure (12) shows the relation of air inlet temperature with the expected $\Delta \omega_{\mathrm{a}}$ across the humidifier for various humidifier lengths $(20 \mathrm{~cm}, 30 \mathrm{~cm}, 40 \mathrm{~cm}, 50 \mathrm{~cm}$ and $60 \mathrm{~cm}$ resp.) and how the expected output humidity ratio increases with the humidifier length.

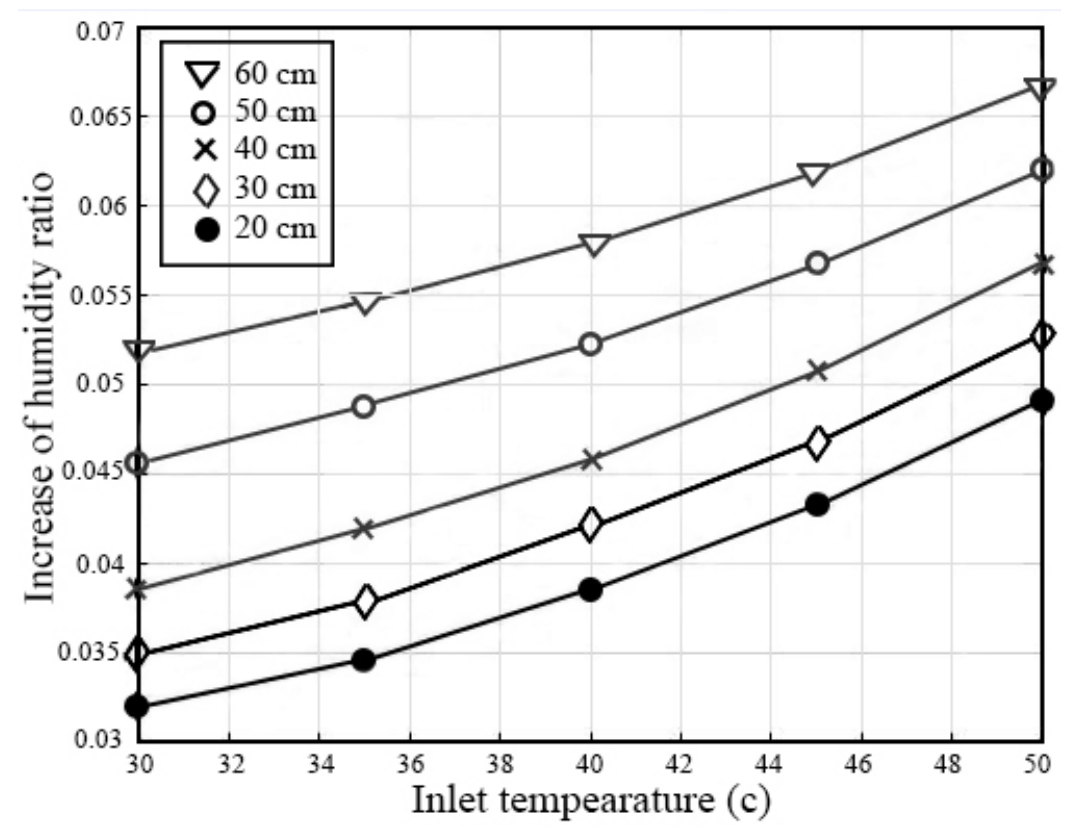

Figure 12 Inlet air temperature and the increase of humidity ratio across humidifier for various humidifier lengths.

Figure (13) illustrates the behavior of air temperature on psychometric chart at different MR values which affects the output air temperature at humidifier exit. MR values are taken at 1, 5 and 10 for comparison at different air inlet temperatures. 


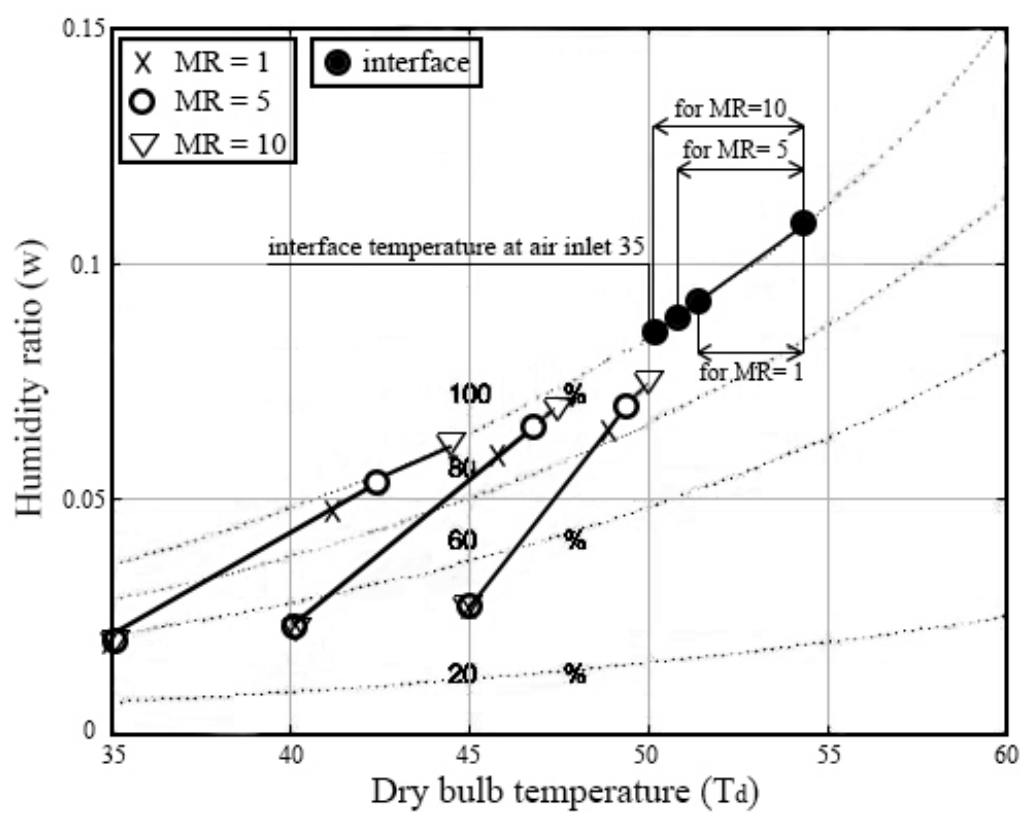

Figure 13 Humidifier cycle representation on the psychometric chart at different MR values

Figure (14) shows the effect of increasing humidity ratio at inlet of humidifier as a constant number and not as a function in the air pressure. As the humidity ratio at inlet increases, the resulting humidity ratio at outlet increases.

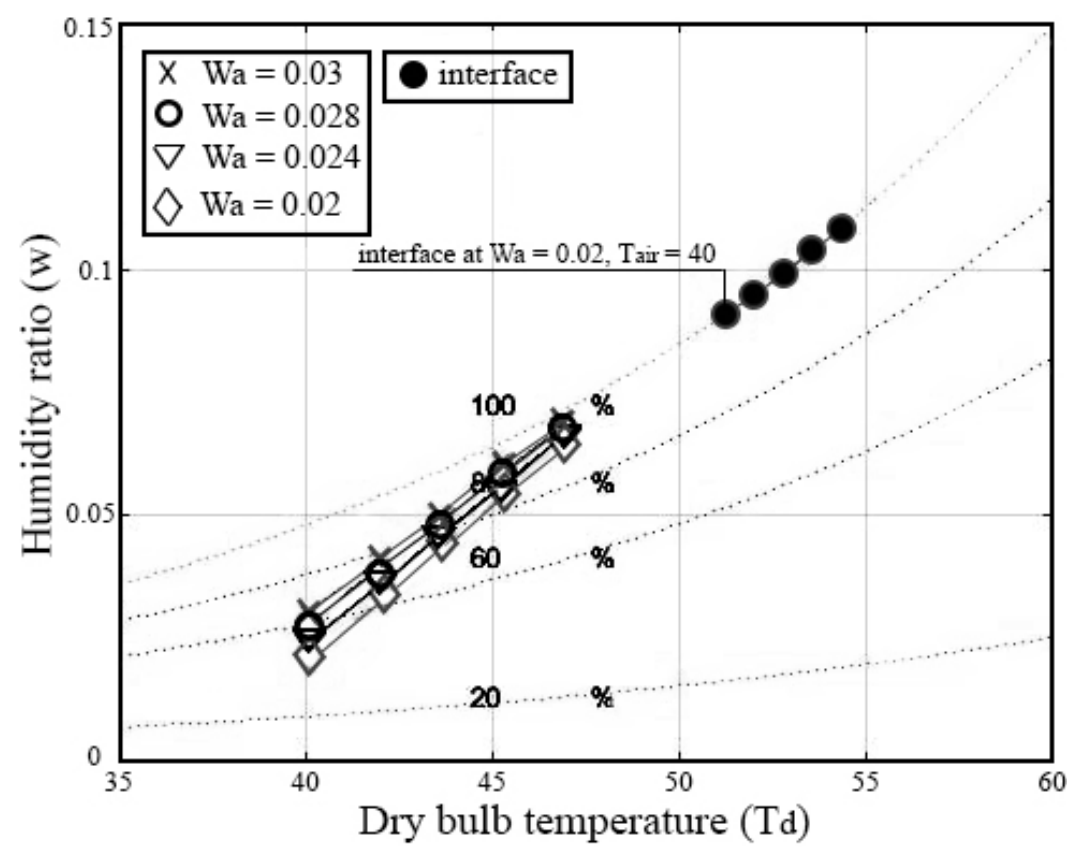

Figure 14 Humidifier cycle representation on the psychometric chart at constant air humidity ratios at inlet.

Figure (15) shows the effect of increasing the specific area of packing material. As the specific area increases, heat transfer process is enhanced and the output air temperature is erased. The specific area of packing material values are $100 \mathrm{~m}^{-1}, 150 \mathrm{~m}^{-1}$ and $200 \mathrm{~m}^{-1}$ at three inlet temperatures $35^{\circ} \mathrm{C}, 40^{\circ} \mathrm{C}$ and $45^{\circ} \mathrm{C}$ to study the effect of specific area of packing material [14]. 
Mohamed Osama, Ehab M. Mina and Raouf N. Abdelmessih, Modeling and optimization of a desalination unit using humidification-dehumidification $\mathrm{HDH}$ principle

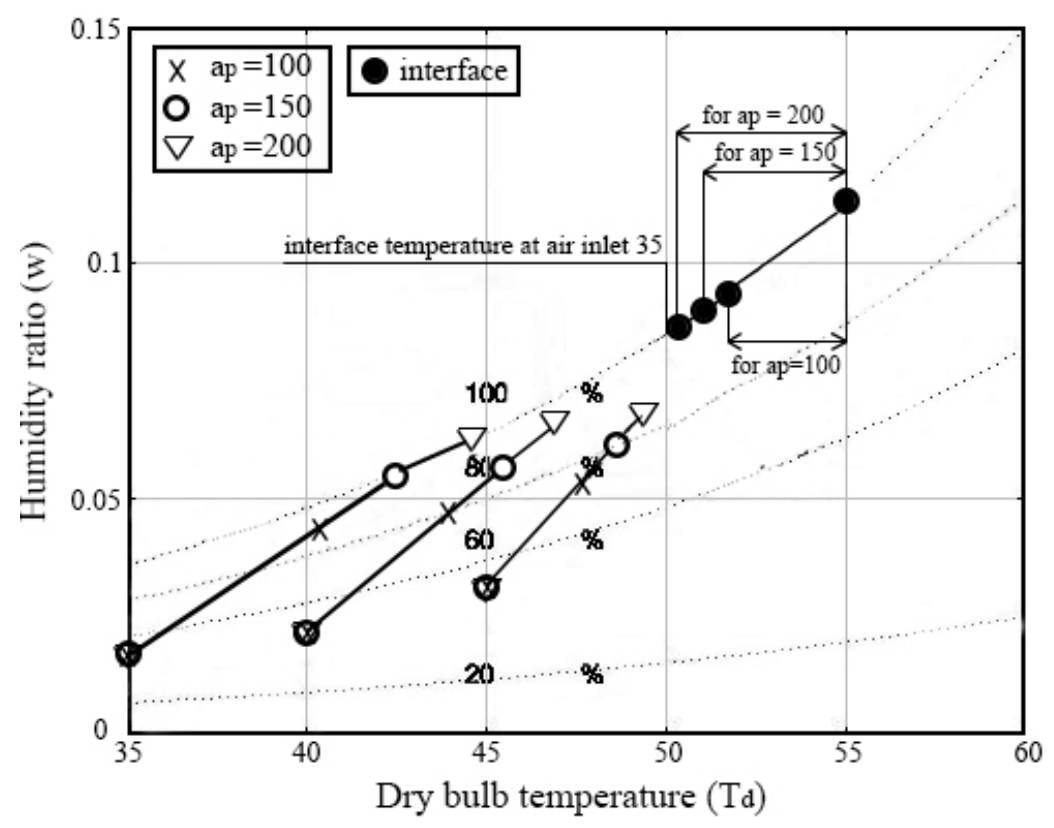

Figure 15 Humidifier cycle representation on the psychometric chart at different packing material specific areas and different inlet air temperatures.

Figure (16) shows the relation between packing material specific area and its effect on the output temperature in the form of $\Delta \mathrm{T}_{\mathrm{a}}$ at air inlet temperatures at $35^{\circ} \mathrm{C}, 40^{\circ} \mathrm{C}$ and $45^{\circ} \mathrm{C} \mathrm{[14]}$.

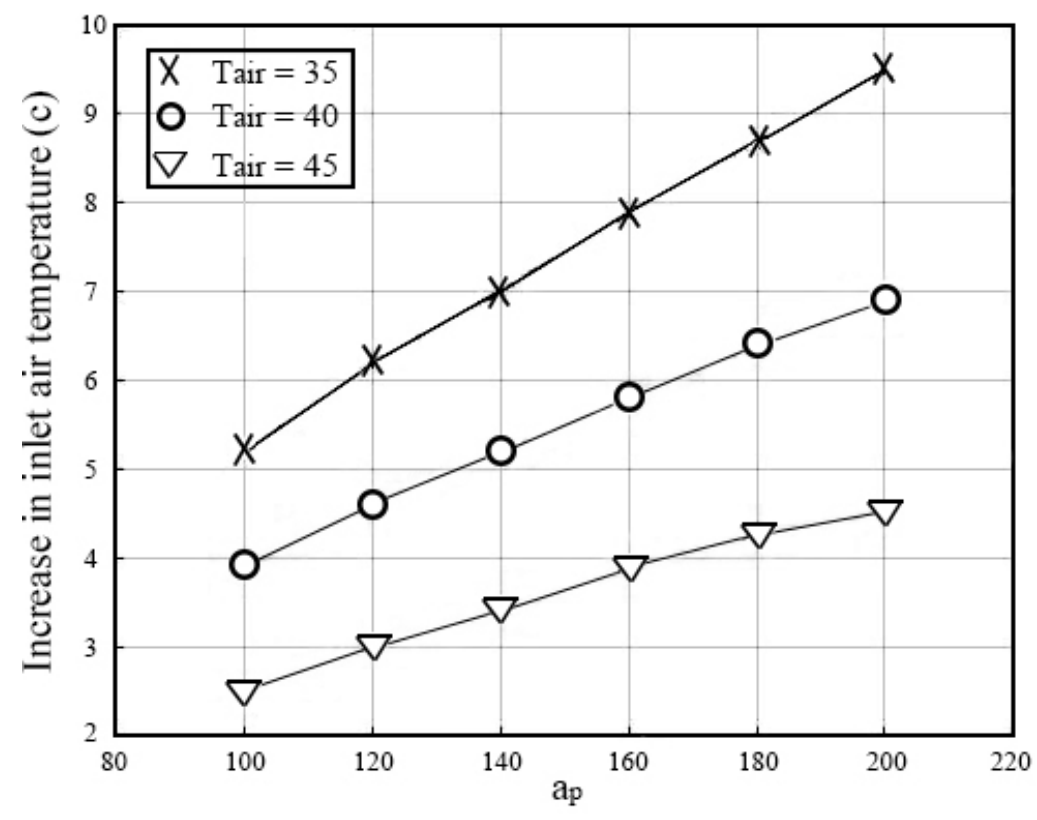

Figure 16 Relation between specific area of packing material and the increase of temperature at different inlet air temperatures.

Figure (17) shows the relation between packing material specific area and its effect of output humidity ratio in the form of $\Delta \omega_{\mathrm{a}}$ at air inlet temperatures at $35^{\circ} \mathrm{C}, 40^{\circ} \mathrm{C}$ and $45^{\circ} \mathrm{C}$ [14]. 


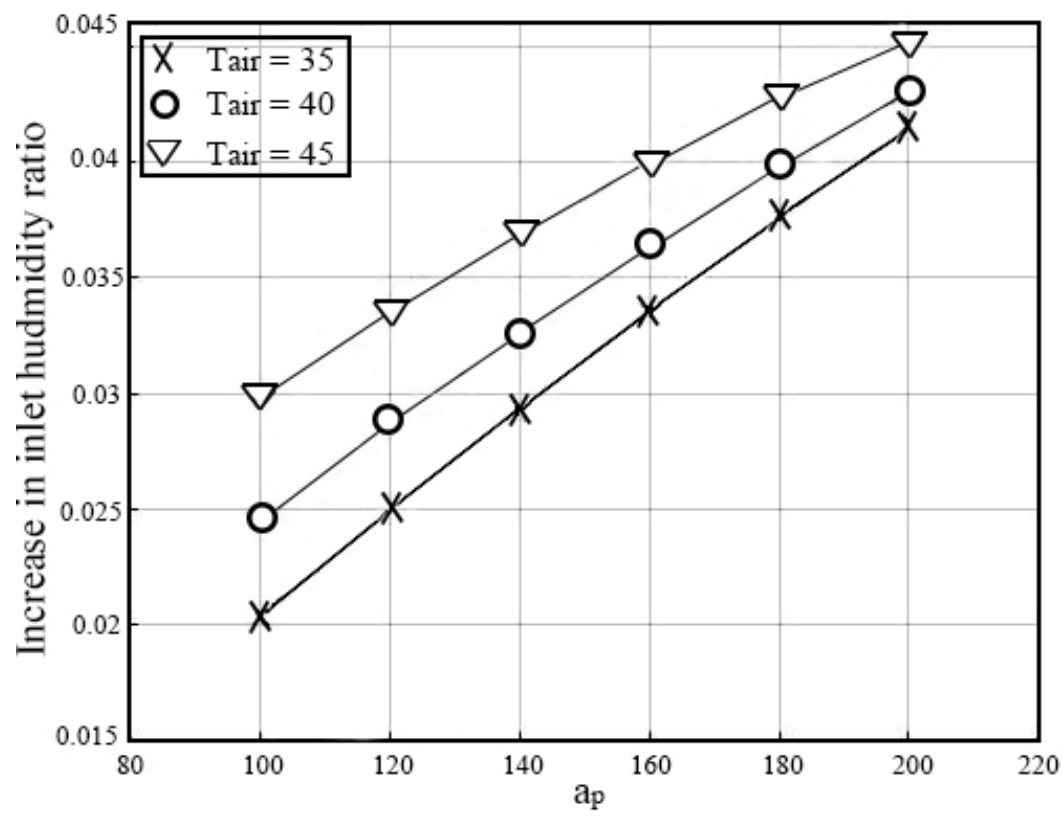

Figure 17 Relation between specific area of packing material and the increase of humidity ratio at different inlet air temperatures.

\subsection{Modeling Dehumidifier}

The second sub-cycle is the dehumidifier sub-cycle. This is the critical section in the HDH cycle as the output of the cycle is gained here.

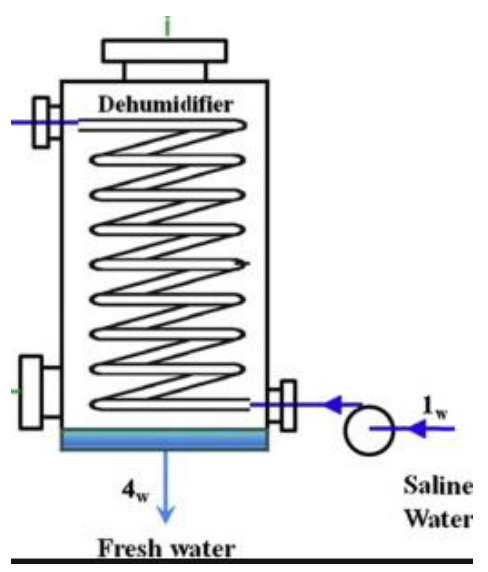

Figure 18 Dehumidifier schematic section

Salt water at atmospheric pressure and relatively cool fluid is pumped by means of a small pump to flow upwards through a tube coil. Hot air with high relative humidity and temperature flows downward over the relatively cold surface temperature coil. Flowing down, the air temperature starts to decrease and condensation of the carried water vapor occurs on the coil surface causing film layer.

Droplets of this fill fall down to the dehumidifier bed. The collected droplets represent the dehumidifier output. The cold water inside the coil gains heat and its temperature increases as it flows up $[13,17,18]$. 
Mohamed Osama, Ehab M. Mina and Raouf N. Abdelmessih, Modeling and optimization of a desalination unit using humidification-dehumidification $\mathrm{HDH}$ principle

\subsubsection{Dehumidifier governing equations}

Assumptions are made up by moving downwards with air across counter flow water flowing inside the coil. Assumption of water temperature at dehumidifier exit takes place and is corrected through several iterations.

$$
\frac{\mathrm{dT}_{\mathrm{a}}}{d y}=\left(\frac{1}{\dot{m}_{\mathrm{a}} * \mathrm{c}_{\mathrm{pa}}}\right) *\left[\mathrm{~h}_{\mathrm{a}} * \mathrm{~A} * \mathrm{a}_{\mathrm{c}} *\left(\mathrm{~T}_{\mathrm{f}}-\mathrm{T}_{\mathrm{a}}\right)\right]
$$

Equation (1) describes the air temperature change which is expected to decrease on moving downwards [16].

$\mathbf{T}_{\mathbf{f}}$ in this equation refers to the temperature of the first droplet of water which will begin to condense on the coil surface and is calculated as follows [16].

$$
\begin{aligned}
& \mathrm{T}_{\mathrm{f}}=\frac{\left(\mathrm{h}_{\mathrm{a}} * \mathrm{~T}_{\mathrm{a}}\right)+\left(\mathrm{h}_{\mathrm{w}} * \mathrm{~T}_{\mathrm{w}}\right)}{\mathrm{h}_{\mathrm{a}}+\mathrm{h}_{\mathrm{w}}} \\
& \frac{\mathrm{dT}_{\mathrm{w}}}{d y}=\left(\frac{1}{\dot{m}_{\mathrm{w}} * \mathrm{C}_{\mathrm{w}}}\right) *\left[\mathrm{~h}_{\mathrm{w}} * \mathrm{~A} * \mathrm{a}_{\mathrm{c}} *\left(\mathrm{~T}_{\mathrm{w}}-\mathrm{T}_{\mathrm{f}}\right)\right]
\end{aligned}
$$

Equation(3) gives us the change in water inside coil temperature which is expected to decrease on moving downwards [16].

$$
\begin{aligned}
& \frac{\mathrm{dT}_{\mathrm{f}}}{d y}=\left(\frac{1}{\dot{m}_{\mathrm{f}} * \mathrm{C}_{\mathrm{w}}}\right) *\left[\mathrm{~h}_{\mathrm{a}} * \mathrm{~A} * \mathrm{a}_{\mathrm{c}} *\left(\mathrm{~T}_{\mathrm{a}}-\mathrm{T}_{\mathrm{f}}\right)+\mathrm{h}_{\mathrm{m}} * \mathrm{~h}_{\mathrm{fg}} * \rho_{\mathrm{a}} * \mathrm{~A} * \mathrm{a}_{\mathrm{c}} *\left(\omega_{\mathrm{a}}-\omega_{\mathrm{f}}\right)+\mathrm{h}_{\mathrm{w}} * \mathrm{~A} * \mathrm{a}_{\mathrm{c}} *\left(\mathrm{~T}_{\mathrm{w}}-\mathrm{T}_{\mathrm{f}}\right.\right. \\
& \quad)]
\end{aligned}
$$

Equation (4) explains the change of film layer temperature which is expected to decrease on moving downwards [16].

$$
\mathrm{h}_{\mathrm{m}}=\frac{\mathrm{h}_{\mathrm{a}}}{\rho_{\mathrm{a}} * \mathrm{c}_{\mathrm{pa}} * \mathrm{Le}^{\wedge}\left(\frac{2}{3}\right)} \text { and } \mathrm{Le}=\frac{\mathrm{Pr}}{S c}
$$

Equation (5) is mass transfer coefficient in addition Lewis number which is ratio between characteristic length for thermal and mass diffusion [14]. Humidity ratio of air equation is given by equation (6) [16].

$$
\begin{aligned}
& \omega_{\mathrm{a}}=0.622 *\left[\frac{\mathrm{P}_{\mathrm{a}}}{P_{a t m}-\mathrm{P}_{\mathrm{a}}}\right] \\
& \mathrm{P}_{\mathrm{a}}=\phi * \mathrm{P}_{\text {sat a }}
\end{aligned}
$$

Equation (7) gives the air pressure for calculating equation (6).

$$
\mathrm{P}_{\text {sat a }}=10^{\wedge}\left[\left(\mathrm{A}-\frac{\mathrm{B}}{\mathrm{C}+\mathrm{T}_{\mathrm{a}}}\right) * 0.001315\right]
$$

Air saturation pressure in equation (8) is obtained from Antoine's equation with its constants. $\mathrm{A}=8.07313, \mathrm{~B}=1730.63, \mathrm{C}=233.4$ [16].

$$
\frac{\mathrm{d} \dot{m}_{\mathrm{f}}}{d y}=\mathrm{h}_{\mathrm{m}} * \rho_{\mathrm{a}} * \mathrm{~A} * \mathrm{a}_{\mathrm{c}} *\left(\omega_{\mathrm{a}}-\omega_{\mathrm{f}}\right)
$$

Equation (9) gives the condensate mass flow rate change over the coil in the dehumidifier, which is expected to increase on moving downwards [16].

$$
\frac{\mathrm{d} \omega_{\mathrm{a}}}{d y}=\frac{1}{\dot{m}_{\mathrm{a}}} *\left(\frac{-\mathrm{d} \dot{m}_{\mathrm{f}}}{d y}\right)
$$

Equation (10) describes how humidity ratio changes, which is expected to decrease on moving downwards [16]. 


\subsubsection{Dehumidifier performance curves}

Equations (1, 3, 4, 10 and 11) are solved for each time step to obtain the change in air temperature, water temperature, film temperature, the condensed mass, and the humidity ratio. A matlab script is used with imbedded integration capabilities to describe the change of the above parameters. Figures (19), (20) and (21) show air temperature behavior with film and water inside coil temperatures on introducing air at different temperatures to the dehumidifier $\left(70^{\circ} \mathrm{C}, 65^{\circ} \mathrm{C}\right.$ and $60^{\circ} \mathrm{C}$ respectively). For all cases, $\mathrm{T}_{\mathrm{w}}=51^{\circ} \mathrm{C}$ and $\mathrm{MR}=5$. The dehumidifier length is $80 \mathrm{~cm}$ long and $\mathrm{a}_{\mathrm{c}}=200 \mathrm{~m}^{-1}$.

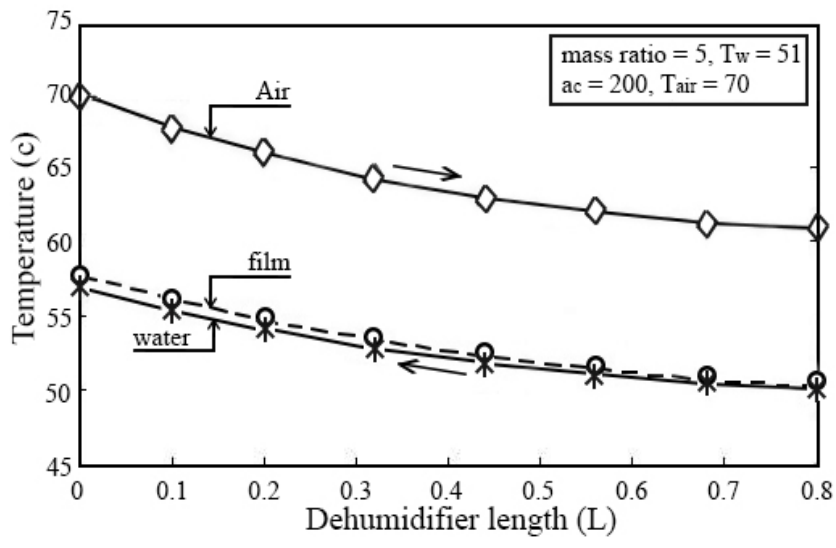

Figure 19 Air temperature behavior at $70^{\circ} \mathrm{C}$

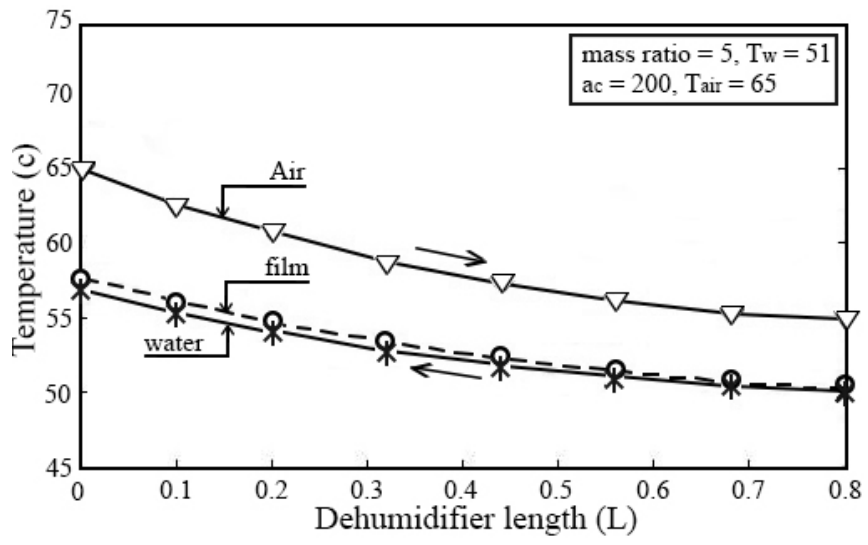

Figure 20 Air temperature behavior at $65^{\circ} \mathrm{C}$

inlet inlet

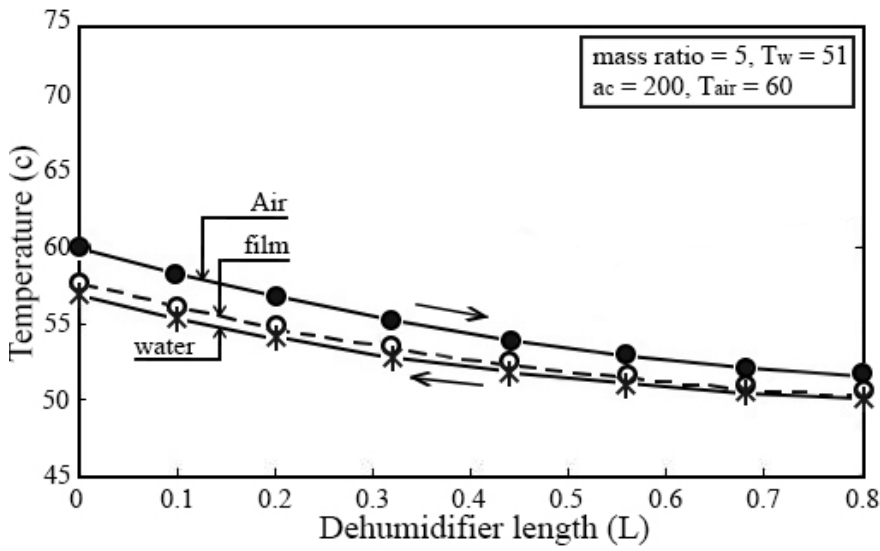

Figure 21 Air temperature behavior at $60^{\circ} \mathrm{C}$ inlet 
Mohamed Osama, Ehab M. Mina and Raouf N. Abdelmessih, Modeling and optimization of a desalination unit using humidification-dehumidification $\mathrm{HDH}$ principle

Figure (22) shows a combined graph for the last three graphs for a clearer representation of air behavior at different inlet temperatures.

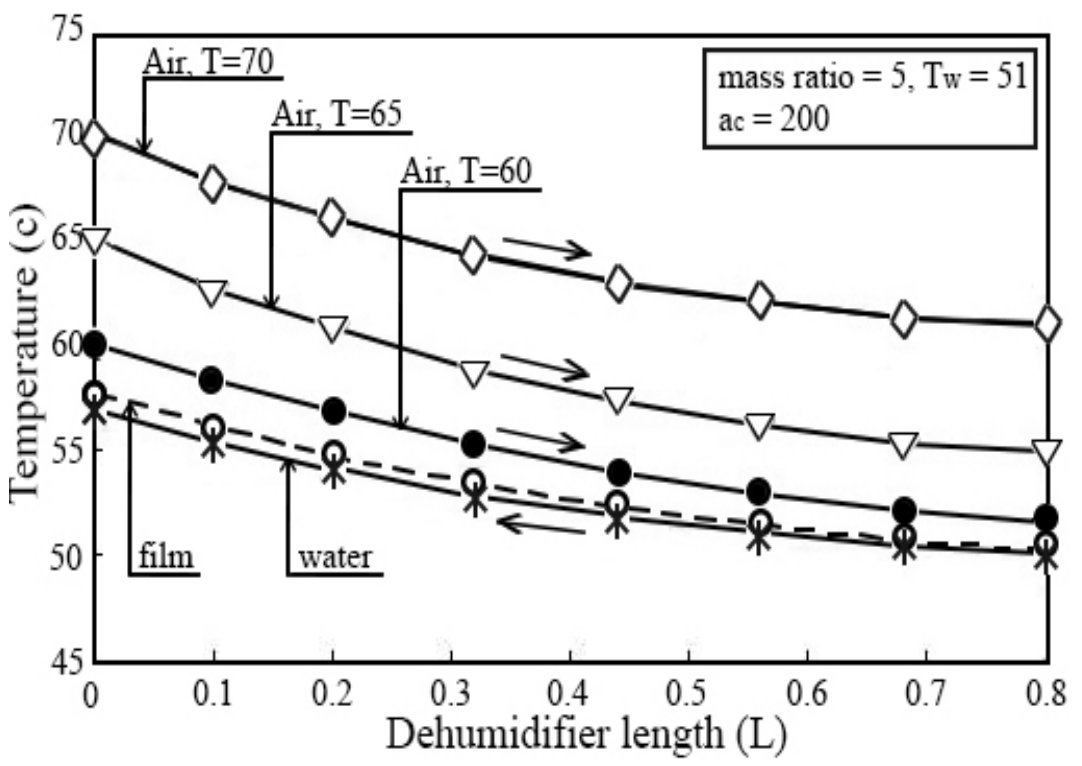

Figure 22 Air, film and water temperature variation along the dehumidifier.

Figure(23) shows the variation in the dehumidifier performance with the change of the inlet air mass flow rate. In this figure the condensed potable water is plotted along the dehumidifier for three air mass flow rate values. The figure shows the effect of changing air mass flow rate on the cycle output. The condensed water increases from $0.018 \mathrm{~kg} / \mathrm{s}$ (at air mass flow of 0.15 $\mathrm{kg} / \mathrm{s}$ ) to $0.02 \mathrm{~kg} / \mathrm{s}$ (at air mass flow of $0.175 \mathrm{~kg} / \mathrm{s}$ ) and finally to $0.022 \mathrm{~kg} / \mathrm{s}$ (at air mass flow of $0.2 \mathrm{~kg} / \mathrm{s}$ ).

The change in the mass flow rates come while keeping other parameters as $\mathrm{T}_{\mathrm{a}}, \mathrm{T}_{\mathrm{w}}, \phi, \mathrm{L}$ and $a_{c}$ at constant values to study the effect of increasing the air mass flow rate only on the condensate mass flow rate (cycle output).

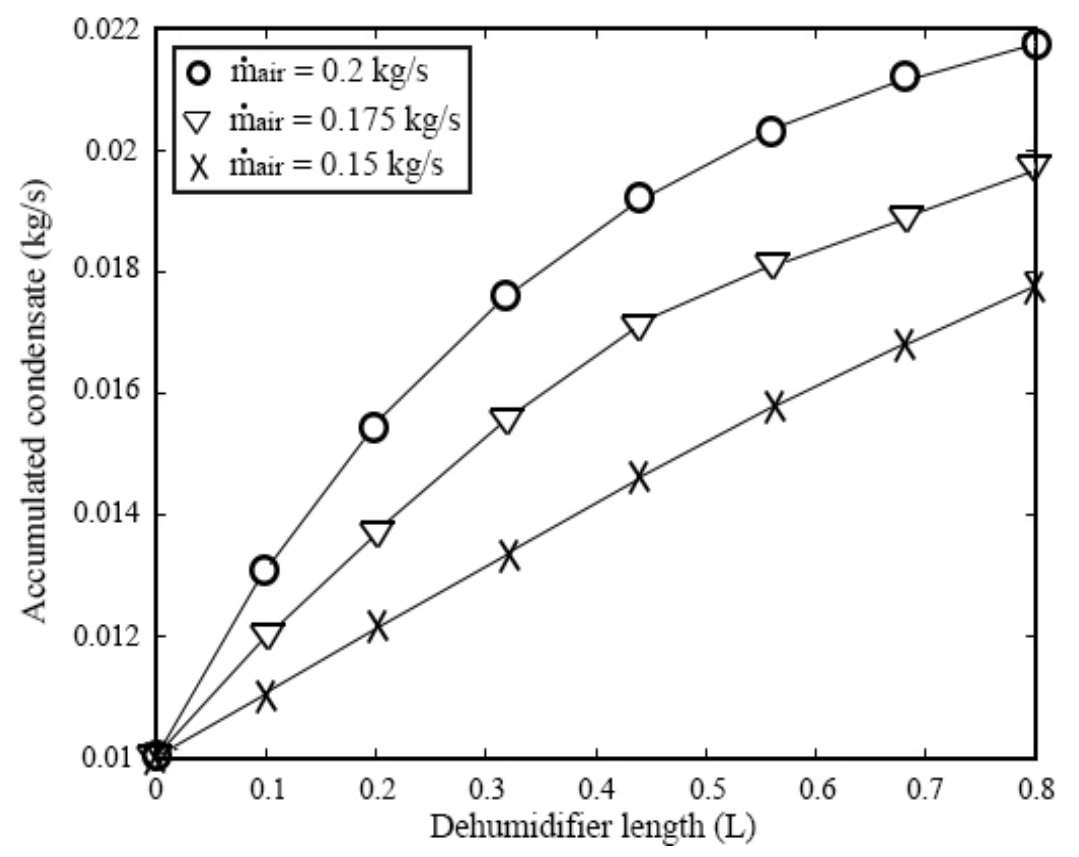

Figure 23 Potable water mass flow rate through dehumidifier. 
Figure (24) shows how the air, film temperature curve behaves at air inlet temperatures equal $70^{\circ} \mathrm{C}$ and $65^{\circ} \mathrm{C}$. Film layers tend to stick to the saturation line.

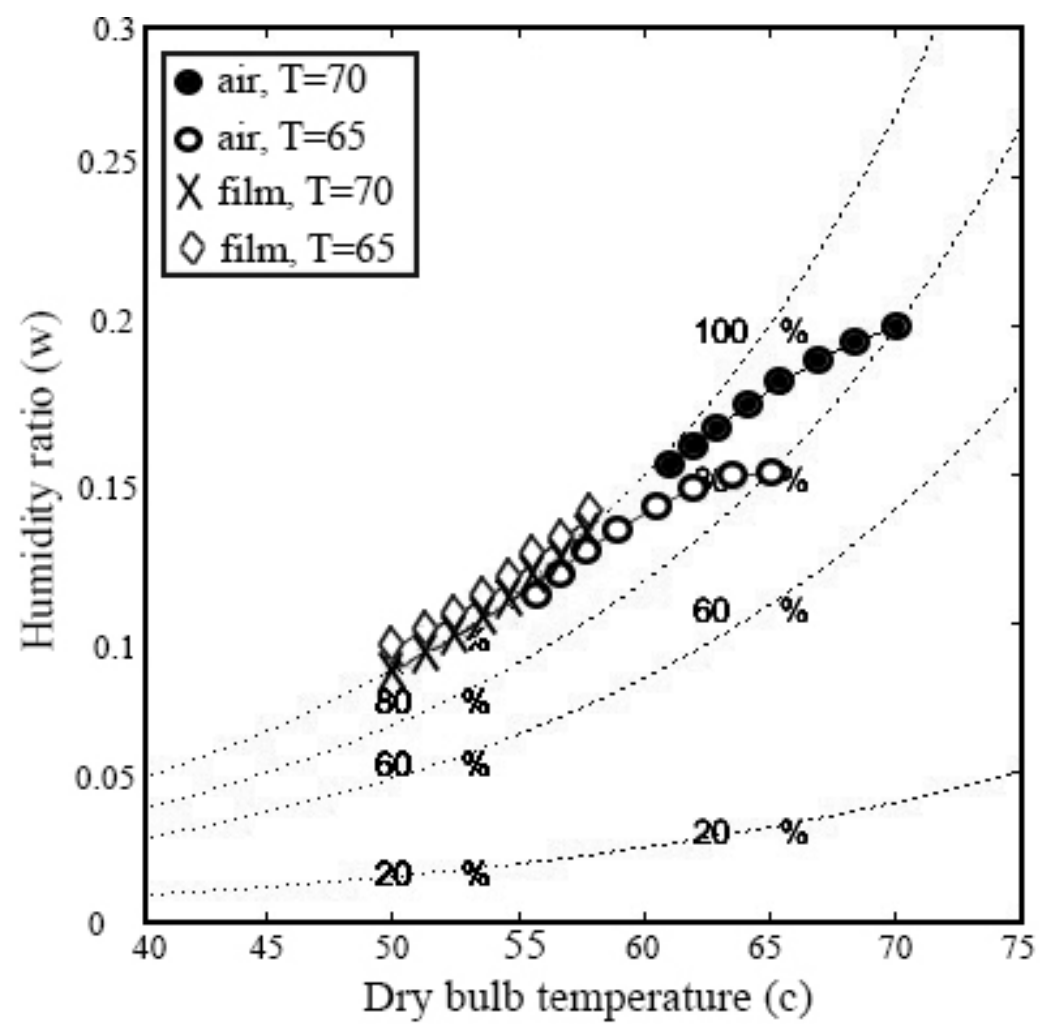

Figure 24 Dehumidifier cycle representation on the psychometric chart at different air inlet temperature.

\section{CONCLUSION}

In this work, a matlab script is used with imbedded integration capabilities in optimizing the rate equations of both humidifier and dehumidifier sections. The outcomes of this study are subroutines that can be integrated to a whole cycle simulation and optimization. Specific results related to each sub-cycle were presented in this paper and could be concluded as follows:

In the humidifier section, several design parameters were studied in the range of mass ratio $\left(\dot{m}_{\mathrm{w}} / \dot{m}_{\text {air }}\right) 1: 5$. The quantitative effect of changing air temperature, humidity ratio and specific area of packing material were studied in terms of change in water carried in the humidifier.

In the dehumidifier section, the behavior of air was studied at different air temperatures and the obtained product mass was studied for different mass ratios

\section{REFERENCES}

[1] Peter Joo Hee Ng, Celine Teo, Singapore's water challenges past to present, 04 Nov. 2019.

[2] H.T.El-Dessouky, H.M. Ettouney, Y. Al-Roumi, Multistage flash desalination: Present and future outlook, Chem. Eng. J. 73 173-190 (1999) .

[3] FilmTecTM Reverse Osmosis membranes technical manual, version 2, Jan.2020.

[4] M.K. Wittholz, B.K. O'Neill, C.B. Colby, D. Lewis, Estimating the cost of desalination plants using a cost database, Desalination 229 10-20 (2008). 
Mohamed Osama, Ehab M. Mina and Raouf N. Abdelmessih, Modeling and optimization of a desalination unit using humidification-dehumidification $\mathrm{HDH}$ principle

[5] Y. Junjie, S. Shufeng, W. Jinhua, L. Jiping, Improvement of a multi-stage flash seawater desalination system for cogeneration power plants, Desalination 217 191-202 (2007).

[6] T.-X. He, L.-J. Yan, Application of alternative energy integration technology in seawater desalination, Desalination 249 104-108 (2009).

[7] A.D. Khawaji,I.K. Kutubkhanah,J.-M. Wie, Advances in seawater desalination technologies, Desalination 221 47-69 (2008).

[8] S. Al-Hallaj, S. Parekh, M.M. Farid, J.R. Selman, Solar desalination with humidificationdehumidification cycle: Review of economics, Desalination 195 169-186 (2006).

[9] R.L. McGinnis, M. Elimelech, Energy requirements of ammonia-carbon dioxide forward osmosis desalination, Desalination 207 370-382 (2007).

[10] Younes Ghalavanda, Mohammad Sadegh Hatamipoura \& Amir Rahimia, A review on energy consumption of desalination processes, a Chemical Engineering Department, University of Isfahan, Isfahan, Iran (2014).

[11] Klausner G.N._Article_Evaporative Heat And Mass Transfer_Evaporative heat and mass transfer for the diffusion driven, Desalination 207 343-357 (2005).

[12] G.P. Narayan and J.H. Lienhard V. Humidification dehumidification desalination. In J. Kucera, editor, Desalination: Water from Water, Chapter 9, pages 425-472 (2014).

[13] G. Prakash Narayan and john H. Lienhard V Roshendhow Kendall, Humidification Dehumidification Desalination, Heat Transfer Laboratory, Massachusetts Institute of Technology, Cambridge, MA 02139-4307 USA (2015).

[14] Saleh H.M., Mina E.M., Abdelmessih R.N., Effects of some design and operation parameters on the performance of a water desalination unit using humidification-dehumidification, International Journal of Mechanical Engineering and Technology 8(5) pp. 681-693 (2017).

[15] G. Prakash Narayan, Mostafa H. Sharqawy, Steven Lam, Sarit K. Das, John H. Lienhard V, Bubble Columns for Condensation at High Concentrations of non-condensable Gas: HeatTransfer Model and Experiments (2013).

[16] Heat Transfer \& Fluid BOOK, Frank P. Incropera, Fundamentals of heat and mass transfer, (2007).

[17] A study on the maximum gained output ratio of single-effect solar humidificationdehumidification desalination (2016).

[18] Optimum Solar-Powered HDH Desalination System for Semi-Isolated Communities (2014). 